\title{
Polyclonal emergence of MDR Enterobacter cloacae complex isolates producing multiple extended spectrum beta-lactamases at Maputo Central Hospital, Mozambique
}

\author{
José Sumbana ${ }^{1,2,3}$ (1) $\cdot$ Antonella Santona ${ }^{2} \cdot$ Maura Fiamma $^{2} \cdot$ Elisa Taviani $^{2,4} \cdot$ Massimo Deligios $^{2} \cdot$ Ventura Chongo $^{3}$. \\ Jahit Sacarlal ${ }^{3} \cdot$ Salvatore Rubino ${ }^{2} \cdot$ Bianca Paglietti $^{2}$
}

Received: 8 September 2021 / Accepted: 20 December 2021 / Published online: 31 January 2022

(c) The Author(s) 2021

\begin{abstract}
Enterobacter spp. are important nosocomial pathogens responsible of a wide variety of infections, mainly due to Extended Spectrum $\beta$-Lactamase (ESBL) producing isolates, constituting a global public health issue in terms of clinical treatment and infection control, especially in low-income countries, where last-line treatment is often unavailable and there is weak nosocomial surveillance. In this study, we conducted a phenotypic and molecular characterization of 8 clinical Enterobacter spp. strains, isolated from patient's blood in three hospitals in Mozambique. Isolates were identified by MALDI-TOF and antimicrobial Susceptibility Testing was performed by VITEK 2 system. Half of isolates were analyzed by PCR for $\beta$-lactamases genes, other isolates by Whole Genome Sequencing. We identified all isolates as Enterobacter cloacae complex (ECC), those from Maputo Central Hospital were polyclonal, multidrug resistant (5/8), and ESBL producers (50\%), carrying $b l a_{\mathrm{CTX}-\mathrm{M}-15}$ and different assortment of $b l a_{\mathrm{SHV}-12}, b l a_{\mathrm{TEM}-1 \mathrm{~B}}$ and $b l a_{\mathrm{OXA}-1}$, and AmpCs $b l a_{\mathrm{CMH}-3}, b l a_{\mathrm{ACT}-7}$ and $b l a_{\mathrm{ACT}-9}$ genes. Resistance determinants linked to fluoroquinolone $\left(a a c\left(6^{\prime}\right) I b-c r\right.$ and $\left.q n r B 1\right)$ and others antimicrobials were also found. Notably, one isolate showed phenotypically resistance to colistin, while another colistin susceptible isolate carried a silent $m c r-9$ gene. ECC nosocomial surveillance is urgently needed to contain and prevent the dissemination of ESBLs producing clones, and mcr-9 spread to other Enterobacteriaceae.
\end{abstract}

Keywords E. cloacae complex $\cdot \mathrm{ESBL}_{\mathrm{CTX}-\mathrm{M}-15 / \mathrm{SHV}-12} \cdot m c r-9 \cdot$ Mozambique

\section{Introduction}

José Sumbana and Antonella Santona have contributed equally to the manuscript.

This paper belongs to a Topical Collection originated from a long scientific collaboration between Mozambican and Italian universities promoted by the Italian Agency for Development Cooperation.

José Sumbana

sumbanajj@gmail.com

1 Department of Biological Sciences, Eduardo Mondlane University, Maputo, Mozambique

2 Department of Earth, Environmental and Life Sciences (DISTAV), University of Genoa, Genoa, Italy

3 Department of Microbiology, Eduardo Mondlane University, Maputo, Mozambique

4 Center of Biotechnology, Eduardo Mondlane University, Maputo, Mozambique
Enterobacter is a member of the ESKAPE group (Enterococcus faecium, Staphylococcus aureus, Klebsiella pneumoniae, Acinetobacter baumannii, Pseudomonas aeruginosa, and Enterobacter species), which includes the 6 most important nosocomial pathogens (Santajit and Indrawattana 2016; Davin-Regli et al. 2019).

Enterobacter spp., are mainly cause of nosocomial infections, including urinary tract infections (UTI), pneumonia, soft tissue infections, endocarditis and septicemia, while they are less commonly found in community-acquired infections (Ramirez and Giron 2020). Enterobacter spp. are associated to multidrug resistance (MDR) phenotypes thanks to their adaptation capability to the hospital environment and their ability to easily acquire resistance and virulence determinants through genetic mobile elements (Uhlemann 2019; Davin-Regli et al. 2019). 
Enterobacter spp. and in general all Enterobacteriaceae, are particularly resistant to beta-lactams, such as natural and synthetic penicillins and cephalosporins of 2 nd and 3rd generation, due to the production of ExpandedSpectrum Beta-Lactamases (ESBLs) (Davin-Regli 2015).

The global emergence of ESBLs represents one of the greatest public health threats in hospitals, and bla $a_{\text {CTX-M-15 }}$ is the most common ESBL gene distributed globally in different clinical strains of Enterobacteriaceae (Rossolini et al. 2008; Sewunet et al. 2021; Awosile and Agbaje 2021) including Enterobacter spp. (Haenni et al. 2016).

Enterobacter spp. isolates harboring $b l a_{\mathrm{CTX}-\mathrm{M}-15}$ and other antimicrobial resistance, including quinolone, aminoglycoside and more recently carbapenem and colistin determinants (Huang et al. 2012; Kananizadeh 2020), constitute a serious health problem due to the lack of treatments (Lim et al. 2010; Osei Sekyere 2016), and increased mortality worldwide (Fernández et al. 2015; Bonomo et al. 2018; Etemadi et al. 2020; Shawa et al. 2021).

In this study, we characterized 8 clinical isolates of Enterobacter cloacae complex strains isolated from bloodstream infections in 3 Mozambican hospitals, 4 of which were analyzed by PCR for $\beta$-lactamases genes and the other isolates by Whole Genome Sequencing (WGS).

To the best of our knowledge this is the first report describing clinical multidrug resistant ESBL-producing Enterobacter cloacae complex isolates in Mozambique.

\section{Materials and methods}

\subsection{Bacterial isolates}

Bacterial isolates were obtained from blood of individual patients at Maputo Central Hospital (MCH), Quelimane Provincial Hospital (QPH) and Quelimane Central Hospital (HCQ) mainly in 2018. Blood samples were collected by aseptically venipuncture in aerobic flasks (Becton-Dickinson, Franklin Lakes, NJ), and transported to the Microbiology Laboratory of Medicine Faculty of Eduardo Mondlane University (MLMF-UEM) and the hospital microbiology laboratories in Quelimane for 5 day culture in BACTEC 9050 instrument (Becton-Dickinson). Preliminary identification of isolates was done through Gram stain and subculture on MacConkey, Chocolate and Blood agar plates at $37{ }^{\circ} \mathrm{C}$ overnight, followed by conventional biochemical tests. Bacterial identifications were confirmed by Matrix-assisted laser desorption ionization-time of flight (MALDI-TOF) (MALDI Biotyper, Bruker Daltonics Inc, USA) at the San Francesco hospital laboratory, Nuoro, Italy.

\subsection{Antibiotic susceptibility testing}

Vitek 2 compact system including specific card GN377 (bioMérieux, Marcy-l'Etoile, France) was used for Antibiotic Susceptibility Testing (AST) according to the guidelines of the European Union Committee for Antimicrobial Susceptibility Testing (EUCAST_2018, http://www.eucast.org/clini cal_breakpoints/).

\subsection{Polymerase chain detection of $\beta$-lactamase genes}

Isolates were tested by $\mathrm{PCR}$ for several resistance genes encoding for ESBLs (TEM, SHV, CTX-M, CTX-M-2, CTXM-9, CTX-M-15, GES, VEB, and PER), AmpCs (MOXM, CITM, DHAM, ACC, EBCM, and FOXM) and Carbapenemases (KPC, OXA-48-like, IMP, VIM, and NDM) using specific primers and protocols (Perez-Perez and Hanson 2002; Dallenne et al. 2010; Hijazi et al. 2016) (Table S1a).

\subsection{Whole genome sequencing}

Bacterial DNA was extracted using Wizard ${ }^{\circledR}$ Genomic DNA Purification Kit (Promega, Madison, WI, USA), and then quantified for WGS using Nanodrop 1000 Spectrophotometer (ThermoFisher, USA). DNAs were sequenced on Illumina NextSeq platform, at a $30 \times$ coverage (NGS Bio, San Francisco) to obtain short reads, which were assembled into contigs using de novo assembly, SPAdes 3.13.0. web-based tool.

Contigs were subjected to in silico analysis for searching antibiotic resistance determinants by ResFinder 3.2 and typing by MLST 2.0, PlasmidFinder 2.0 and pMLST 2.0, available at the Center for Genomic Epidemiology (CGE) (http://www.genomicepidemiology.org/).

\section{Results}

\subsection{E. cloacae complex isolates identification and antimicrobial susceptibilities}

Eight clinical Enterobacter spp. strains, isolated from blood in 2018 at the Maputo Central Hospital $(n=5)$, at Quelimane Provincial Hospital $(n=2)$ and at Quelimane Central Hospital $(n=1)$ were identified as Enterobacter cloacae complex (ECC) by MALDI-TOF.

The ECC isolates were resistant to trimethoprim-sulfamethoxazole $(75 \%)$, gentamicin $(50 \%)$, ciprofloxacin and fosfomycin (25\%), colistin (13\%), and all were susceptible to 
Table 1 MIC values (mg/L) of antimicrobial agents for 8 Enterobacter cloacae complex isolates from Mozambican hospitals

\begin{tabular}{llll}
\hline Antimicrobial agents & $\begin{array}{l}\text { Breakpoint for resist- } \\
\text { ance }(\mathrm{mg} / \mathrm{L})\end{array}$ & $\begin{array}{l}\text { No. of resistant } \\
\text { isolates }(\%)\end{array}$ & MIC data (mg/L) range \\
\hline Piperacillin-tazobactam & $>16$ & $3(38 \%)$ & $\leq 4$ to $\geq 128$ \\
Cefotaxime & $>2$ & $4(50 \%)$ & $\leq 0.25$ to $\geq 64$ \\
Ceftazidime & $>4$ & $4(50 \%)$ & $\leq 0.12$ to $\geq 64$ \\
Ertapenem & $>1$ & 0 & $\leq 0.12$ \\
Meropenem & $>8$ & 0 & $\leq 0.25$ \\
Amikacin & $>16$ & 0 & $\leq 1$ to 4 \\
Gentamicin & $>4$ & $4(50 \%)$ & $\leq 1$ to $\geq 16$ \\
Ciprofloxacin & $>0.5$ & $2(25 \%)$ & $\leq 0.06$ to $\geq 4$ \\
Tigecycline & $>2$ & 0 & $\leq 0.5$ to 1 \\
Fosfomycin & $>32$ & $2(25 \%)$ & $\leq 0.16$ to 128 \\
Colistin & $>2$ & $1(13 \%)$ & $\leq 0.5$ to $\geq 16$ \\
Trimethoprim-sulfamethoxazole & $>4$ & $6(75 \%)$ & $\leq 0.16$ to $\geq 320$ \\
\hline
\end{tabular}

MIC Minimum inhibitor concentration ertapenem, meropenem, amikacin and tigecycline (Table 1). Notably, $50 \%$ of isolates were MDR and $63 \%$ ESBL producers. The antimicrobial MICs are shown in Table 1.

\subsection{Molecular typing and antimicrobial genetic determinants}

Four Sequence Type (ST) were identified by in silico Multi Locus Sequence Type (MLST), including ST84, ST125 and two new ST, with new mutations in 3 (dnaA, leuS and gyrB) and 4 (dnaA, leuS, pyrG and $r p l B)$ alleles, respectively (under submission at the Enterobacter cloacae MLST database for STs assignation).

Fifty percent of ECC isolates, all from MCH, were ESBL producing strains (Table 1Sb). The ST84, ST125 clones and one untyped E. cloacae complex isolate (SSM111) carried $b l a_{\mathrm{CTX}-\mathrm{M}-15}$, and one also carried the $b l a_{\mathrm{SHV}}$ gene. The bla $a_{\mathrm{SHV} 12}$ was also found in one of the new ST (SSM110). In addition, bla $_{\mathrm{CMH}-3}(n=1)$, bla $a_{\mathrm{ACT}-7}(n=1)$, and bla $_{\mathrm{ACT}-9}$ $(n=1)$ genes and other $\beta$-lactamase genes, $b l a_{\mathrm{TEM}-1 \mathrm{~B}}(n=3)$ and bla $_{\mathrm{OXA}-1}(n=2)$ were found (Table $\left.1 \mathrm{Sb}\right)$.

Aminoglycoside and quinolone resistance were linked to aminoglycosides modifying enzymes [aac(3)-IIa, $\operatorname{aac}(3)$ $I I d, \operatorname{aac}\left(6^{\prime}\right)-I I C, \operatorname{aph}\left(3^{\prime}\right)-I a, \operatorname{aph}\left(3^{\prime \prime}\right)-I b$, and $\left.a p h(6)-I d\right]$ and plasmid mediated quinolone resistance genes $\left[a a c\left(6^{\prime}\right) I b-c r\right.$ and $(q n r B 1)]$, respectively, Moreover, we identified aminoglycoside adenyltransferases ( $a a d A 1$ and $a a d A 2)$ encoding resistance to streptomycin/spectinomycin agents. Trimethoprim-sulfamethoxazole resistance determinants were $d f r A l$ $(n=1), d f r A 14(n=2)$ and $d f r A 19(n=1)$.

Furthermore, we also detected sulfonamides (sull and sul2), tetracyclines $[\operatorname{tet}(A)$ and $\operatorname{tet}(D)]$, fosfomycin $(\operatorname{fos} A)$, chloramphenicols (catA1, catA2 and catB3) and macrolides $[\operatorname{mph}(A)$ and $\operatorname{ere}(\mathrm{A})]$ resistance determinants (Table $1 \mathrm{Sb})$.
The ST84 isolate showed colistin phenotypic resistance (MIC $>=16$ ) without harboring plasmid acquired $\mathrm{mcr}$ colistin resistance genes, while one new ST isolate (SSM110) was susceptible to colistin even if harboring the $m c r-9$ gene (Table S1b).

We also checked for $m g r B, p m r A B$ and phoQP genes, described to be involved in colistin resistance in Enterobacter spp. The comparison analysis of each gene sequence of our isolates with the ATCC 13047 E. cloacae strain (NC_014121) showed several mutations with $p m r A B$ having $81 \%$ of identity, but none sequences showed missense mutations in the corresponding translated proteins.

We also checked for the qseCB gene (linked with $\mathrm{mcr}$ 9 functionality), in the $m c r-9$ positive E. cloacae complex isolate (SSM110). We detected both qseBC genes (Node_2), showing $100 \%$ and $99 \%$ of nucleotide identity with Enterobacter hormaechei subsp. hormaechei strain 34,983, respectively. Of the 3 missense mutations (A353G, TQ37677AR) on the QseC translated protein (AJB72359), only one (A267V) was also detected in the QseC protein of Enterobacter hormaechei CFSAN080736 strain (HAZ0554290).

The CTX-M-15 and SHV-12 ESBLs were likely associated with $\operatorname{IncHI} 2$ or IncHI2A (Type 1) plasmids as well as the $m c r-9$ gene. IncFIB and IncFII plasmid replicons were also found (Table S1b).

\section{Discussion}

The global emergence and spread of multidrug resistant Gram-negative pathogens producing $\beta$-lactamases, including ESBL, AmpC and carbapenemase, has become a serious public health problem because of their association with nosocomial and community-acquired infections worldwide 
(Jacoby and Munoz-Price 2005; Nordmann et al. 2011; Beyene et al. 2019).

ESBLs are often associated with other resistance genes (e.g., quinolone PMQR genes, aminoglycoside genes), mainly found within conjugative plasmids or other mobile genetic elements, which can be transmitted intra and interspecies, conferring resistance to antimicrobials extensively used in human and animals (Jiang et al. 2008; Rozwandowicz et al. 2018). This constitutes a worrisome situation especially in low-income countries, where last-line treatments are often unavailable (Meunier et al. 2017; Frost et al. 2019; Annavajhala et al. 2019; Nishida et al. 2020). Moreover, the plasmid-mediated polymyxin resistance ( $\mathrm{mcr}$ genes), are also increasing worldwide (Nang et al. 2019), further decreasing available therapeutic choices.

The emergence of ESBLs among Enterobacteriaceae, have been observed mainly in Klebsiella spp., E. coli but also in Enterobacter spp., Proteus spp., Morganella spp., Citrobacter spp., Providencia spp., and Salmonella spp (Pitout et al. 2005; Haenni et al. 2016).

CTX-M-15 is the most widely distributed $b l a_{\text {CTX-M }}$ gene on a global scale among Enterobacteriaceae, it has been associated with other ESBLs including carbapenemase and also with colistin resistance determinants (Ribeiro et al. 2016; Zeynudin et al. 2018; Soliman et al. 2020; Awosile and Agbaje 2021).

In this study, we reported the presence of a polyclonal MDR Enterobacter cloacae complex circulating in the Maputo Central Hospital, Mozambique. Four out of 5 isolates were ESBL producing strains carrying $b l a_{\text {CTX-M-15, }}$ $b l a_{\mathrm{SHV}}$ genes and additional determinants involved in $\beta$-lactam resistance, including $b l a_{\mathrm{CMH}-3}, b l a_{\mathrm{ACT}-7}$, bla $a_{\mathrm{ACT}-9 \text {, }}$ $b_{\text {TEM-1B }}$, and $b_{\text {OXA-1 }}$ genes.

CTX-M-15 has been reported in Mozambique, particularly in Klebsiella pneumoniae and E. coli isolates, associated with invasive and non-invasive infections (Pons et al. 2015; Guiral et al. 2018). In addition, recent studies carried out at $\mathrm{MCH}$ reported the dominance of CTX-M-15 and AmpC-genes in E. coli isolated from urine and blood cultures (Estaleva et al. 2021) and the occurrence of a pandemic E. coli ST405 clone coharboring $b l a_{\mathrm{NDM}-5}$ and $b l a_{\mathrm{CTX}-\mathrm{M}-15}$ (Sumbana et al. 2021).

Always in Maputo, bla $a_{\text {CTX-M-15 }}$ producing E. coli and Klebsiella spp., also harboring AmpC genes, were detected from colonized university students (Chirindze et al. 2018).

To date, no ESBL genes were reported in Enterobacter spp. in Mozambique, even if third and fourth generation cephalosporin resistant and MDR Enterobacter spp. isolates were phenotypically detected, in both pediatric and adult wards at $\mathrm{MCH}$, resulting the most resistance species among enterobacteria at MCH (Mahaluca et al. 2019).

Our study showed E. cloacae complex isolates harboring $b l a_{\mathrm{CTX}-\mathrm{M}-15}$, circulating at the MCH. In the same hospital,
Klebsiella spp. and $E$. coli isolates, carrying the bla $a_{\mathrm{CTX}-\mathrm{M}-15}$ were isolated since 2015 (Estaleva et al. 2021; Sumbana et al. 2021), which may have contributed to the spread of the resistance. These finding reinforce the idea that at $\mathrm{MCH}$, penicillins and beta-lactam antibiotics are not suitable for the treatment of infections caused by Enterobacteriaceae.

ESBL producing $E$. cloacae complex isolates from this study were MDR, carrying multiple aminoglycoside modifying enzymes and quinolone determinants, further narrowing the therapeutic choices.

Moreover, one isolate (ST84) showed phenotypically resistance to colistin, while a new ST colistin susceptible isolate, carried a silent $m c r-9$ gene.

Colistin resistance can be mediated by chromosomal genes ( $p h o P Q$, $p m r A B$, and $m g r B$ ), altering the structure of lipopolysaccharides (Esposito et al. 2017; Osei Sekyere 2019), and by plasmid-mediated mobilized colistin-resistance $m c r$-like genes (namely, from $m c r-1$ to $m c r$-10) (Osei Sekyere 2019; Wang et al. 2020), where $m c r-1$ is the predominant genetic variant in human and other sources in Africa (Olowo-okere and Yacouba, 2020).

Here, we did not find any missense mutation in the PhoPQ, PmrAB two-Component regulatory systems nor in $\mathrm{MgrB}$, the negative feedback regulator of the PhoQ-PhoP signaling system. This validated a recent study, which showed that, unlike in Klebsiella spp. and E. coli, the PhoQ and $\mathrm{PmrB}$ proteins were not overexpressed in E. cloacae colistin-resistant isolates, suggesting that the colistin resistance mechanisms might be different in E. cloacae when compared to other gram-negative bacteria (Hong and Ko 2019).

Therefore, other mechanisms in Enterobacter spp., including overexpression of efflux-pump or overproduction of capsule (Olaitan et al. 2014; Aghapour et al. 2019) may be involved in colistin chromosomal resistance in our isolates and further studies are necessary to clarify the adaptation mechanisms involved in colistin resistance.

We also reported the occurrence of the $m c r-9$ gene from a colistin-susceptible E. cloacae complex isolate, carrying other antimicrobial resistance genes.

The gene $m c r-9$, mainly carried in $I n c \mathrm{HI} 2$ plasmids ( $\mathrm{Li}$ et al. 2020), has been reported in several countries including USA, China, Sweden, and France with human and animal origins (Li et al. 2020; Börjesson et al. 2020). In accordance with our findings, Enterobacter spp. harboring $m c r-9$, without expressing the gene product, was previously reported from a pediatric patient in United States hospitals (Kananizadeh 2020) and from Japan (Chavda et al. 2019). The lack of the two potential regulatory genes system (qseCB), was shown to play a role in the inducibility of $m c r-9$ (Kieffer et al. 2019; Kananizadeh 2020). However, other components as yet undetermined including genes or molecules might 
regulate $m c r$-9 expression (Clarke and Sperandio 2005; Kananizadeh 2020).

In this study, we detected both qseCB genes in the $\mathrm{mcr}$ 9 positive E. cloacae complex isolate, showing missense mutations on the QseC protein. However, additional studies are necessary to clarify if these mutations or other mechanisms are implicated in the lack of functionality of the $m c r-9$ gene.

The silence of $m c r-9$ gene constitutes a concern, since increases MIC have been noted following colistin exposure (Kieffer et al. 2019), and these bacteria may serve as reservoirs of colistin antibiotic resistance without being detected phenotypically. In these isolates, also the use of polymyxins is strongly discouraged.

Bacterial strategies of resistances to polymyxins, including alterations of lipopolysaccharides, utilization of efflux pumps and capsule formation (Olaitan et al. 2014) could also play an important role in Enterobacteriaceae isolates at $\mathrm{MCH}$ suggesting antimicrobial surveillance reinforcement.

\section{Conclusion}

There is the need of a rational use of cephalosporins at $\mathrm{MCH}$, due to the high $\beta$-lactamases (ESBLs and AmpCs) presence in Enterobacteria and a rational use of colistin since it could activate the silence $m c r-9$ gene found in a ECC isolate.

An improvement of the hygiene rules and a large-scale epidemiological surveillance are strongly recommended at $\mathrm{MCH}$ to avoid the dissemination of ESBLs and mcr-9 plasmid among Enterobacteria.

Supplementary Information The online version contains supplementary material available at https://doi.org/10.1007/s12210-021-01039-4.

Acknowledgements The authors would like to stuff of Microbiology Laboratory of Maputo Central Hospital, for their commitment and co-operation. BP is supported by Sardinian Region [POR-FSE 20142020-Asse Prioritario 3 "Istruzione e Formazione"-Obiettivo Tematico: 10, Priorità d'investimento: 10ii, Obiettivo Specifico: 10.5, Azione dell'Accordo di Partenariato 10.5.12-C.U.P. J86C18000270002].

Funding This work was supported by Ministry of Science and Technology, Higher Education and Vocational Technical of Mozambique and partially supported by the project "Training in Biodiversity and Biotechnology, AID11096", of the Italian Agency for International Cooperation-AICS.

\section{Declarations}

Conflict of interest There is no conflict of interest.
Ethics approval and bacterial identification The study was approved by National Health Bioethics Committee (CNBS) of Mozambique with (Ref 78/CNBS/2017) reference.

Open Access This article is licensed under a Creative Commons Attribution 4.0 International License, which permits use, sharing, adaptation, distribution and reproduction in any medium or format, as long as you give appropriate credit to the original author(s) and the source, provide a link to the Creative Commons licence, and indicate if changes were made. The images or other third party material in this article are included in the article's Creative Commons licence, unless indicated otherwise in a credit line to the material. If material is not included in the article's Creative Commons licence and your intended use is not permitted by statutory regulation or exceeds the permitted use, you will need to obtain permission directly from the copyright holder. To view a copy of this licence, visit http://creativecommons.org/licenses/by/4.0/.

\section{References}

Aghapour Z, Gholizadeh P, Ganbarov K, Bialvaei AZ, Mahmood SS, Tanomand A, Yousefi M, Asgharzadeh M, Yousefi B, Samadi Kafil H (2019) Molecular mechanisms related to colistin resistance in Enterobacteriaceae. IDR 12:965-975. https://doi.org/10. 2147/IDR.S199844

Annavajhala MK, Gomez-Simmonds A, Uhlemann A-C (2019) Multidrug-resistant Enterobacter cloacae complex emerging as a global, diversifying threat. Front Microbiol 10:44. https://doi. org/10.3389/fmicb.2019.00044

Awosile BB, Agbaje M (2021) Genetic environments of plasmid-mediated blaCTXM-15 beta-lactamase gene in Enterobacteriaceae from Africa. Microbiol Res 12:383-394. https://doi.org/10.3390/ microbiolres 12020026

Beyene D, Bitew A, Fantew S, Mihret A, Evans M (2019) Multidrugresistant profile and prevalence of extended spectrum $\beta$-lactamase and carbapenemase production in fermentative Gram-negative bacilli recovered from patients and specimens referred to National Reference Laboratory, Addis Ababa, Ethiopia. PLoS ONE 14:e0222911. https://doi.org/10.1371/journal.pone.0222911

Bonomo RA, Burd EM, Conly J, Limbago BM, Poirel L, Segre JA, Westblade LF (2018) Carbapenemase-producing organisms: a global scourge. Clin Infect Dis 66:1290-1297. https://doi.org/10. 1093/cid/cix893

Börjesson S, Greko C, Myrenås M, Landén A, Nilsson O, Pedersen K (2020) A link between the newly described colistin resistance gene $m c r-9$ and clinical Enterobacteriaceae isolates carrying blaSHV-12 from horses in Sweden. J Glob Antimicrob Resist 20:285-289. https://doi.org/10.1016/j.jgar.2019.08.007

Chavda KD, Westblade LF, Satlin MJ, Hemmert AC, Castanheira M, Jenkins SG, Chen L, Kreiswirth BN (2019) First report of bla VIM-4 - and $m c r$-9-coharboring Enterobacter species isolated from a pediatric patient. mSphere 4:e00629-e719. https://doi.org/10. 1128/mSphere.00629-19

Chirindze LM, Zimba TF, Sekyere JO, Govinden U, Chenia HY, Sundsfjord A, Essack SY, Simonsen GS (2018) Faecal colonization of $E$ coli. and Klebsiella spp. producing extended-spectrum beta-lactamases and plasmid-mediated AmpC in Mozambican university students. BMC Infect Dis. https://doi.org/10.1186/ s12879-018-3154-1

Clarke MB, Sperandio V (2005) Transcriptional autoregulation by quorum sensing Escherichia coli regulators B and C (QseBC) in enterohaemorrhagic E. coli (EHEC): QseBC autoregulation in EHEC. Mol Microbiol 58:441-455. https://doi.org/10.1111/j. 1365-2958.2005.04819.x 
Dallenne C, Da Costa A, Decré D, Favier C, Arlet G (2010) Development of a set of multiplex PCR assays for the detection of genes encoding important $\beta$-lactamases in Enterobacteriaceae. J Antimicrob Chemother 65:490-495. https://doi.org/10.1093/jac/dkp498

Davin-Regli A (2015) Enterobacter aerogenes and Enterobacter cloacae; versatile bacterial pathogens confronting antibiotic treatment. Front Microbiol 6:10

Davin-Regli A, Lavigne J-P, Pagès J-M (2019) Enterobacter spp.: update on taxonomy, clinical aspects, and emerging antimicrobial resistance. Clin Microbiol Rev 32:32

Esposito F, Fernandes MR, Lopes R, Muñoz M, Sabino CP, Cunha MP, Silva KC, Cayô R, Martins WMBS, Moreno AM, Knöbl T, Gales AC, Lincopan N (2017) Detection of colistin-resistant MCR-1-positive Escherichia coli by use of assays based on inhibition by EDTA and zeta potential. J Clin Microbiol 55:3454-3465. https://doi.org/10.1128/JCM.00835-17

Estaleva CEL, Zimba TF, Sekyere JO, Govinden U, Chenia HY, Simonsen GS, Haldorsen B, Essack SY, Sundsfjord A (2021) High prevalence of multidrug resistant ESBL- and plasmid mediated AmpC-producing clinical isolates of Escherichia coli at Maputo Central Hospital, Mozambique. BMC Infect Dis 21:16. https:// doi.org/10.1186/s12879-020-05696-y

Etemadi S, Ebrahimzadeh Leylabadlo H, Ghotaslou R (2020) AmpC $\beta$-lactamase among Enterobacteriaceae: a new insight. Gene Reports 19:100673. https://doi.org/10.1016/j.genrep.2020.100673

Fernández J, Montero I, Martínez Ó, Fleites A, Poirel L, Nordmann P, Rodicio MR (2015) Dissemination of multiresistant Enterobacter cloacae isolates producing OXA-48 and CTX-M-15 in a Spanish hospital. Int J Antimicrob Agents 46:469-474. https:// doi.org/10.1016/j.ijantimicag.2015.07.003 (Epub 2015 Aug 7 PMID: 26307466)

Frost I, Craig J, Joshi J, Faure K, Laxminarayan (2019) R Center for Disease Dynamics, Economics \& Policy, Washington DC, 26

Guiral E, Pons MJ, Vubil D, Marí-Almirall M, Sigaúque B, Soto SM, Alonso PL, Ruiz J, Vila J, Mandomando I (2018) Epidemiology and molecular characterization of multidrug-resistant Escherichia coli isolates harboring blaCTX-M group 1 extended-spectrum \& beta-lactamases causing bacteremia and urinary tract infection in Manhiça, Mozambique. IDR 11:927-936. https://doi.org/10. 2147/IDR.S153601

Haenni M, Saras E, Hocquet D, Madec J-Y (2016) High prevalence of international ESBL CTX-M-15-producing Enterobacter cloacae ST114 clone in animals. J Antimicrob Chemother 71:1497-1500. https://doi.org/10.1093/jac/dkw006

Hijazi SM, Fawzi MA, Ali FM, Abd El Galil KH (2016) Prevalence and characterization of extended-spectrum beta-lactamases producing Enterobacteriaceae in healthy children and associated risk factors. Ann Clin Microbiol Antimicrob 15:3. https://doi.org/10. 1186/s12941-016-0121-9

Hong Y-K, Ko KS (2019) PmrAB and PhoPQ Variants in ColistinResistant Enterobacter spp. Isolates in Korea. Curr Microbiol 76:644-649. https://doi.org/10.1007/s00284-019-01672-1

Huang S, Dai W, Sun S, Zhang X, Zhang L (2012) Prevalence of plasmid-mediated quinolone resistance and aminoglycoside resistance determinants among carbapeneme non-susceptible Enterobacter cloacae. PLoS ONE 7:8

Jacoby GA, Munoz-Price LS (2005) The new $\beta$-lactamases. N Engl J Med 352:380-391. https://doi.org/10.1056/NEJMra041359

Jiang Y, Zhou Z, Qian Y, Wei Z, Yu Y, Hu S, Li L (2008) Plasmidmediated quinolone resistance determinants $q n r$ and $a a c(60)-I b$ $c r$ in extended-spectrum $\beta$-lactamase-producing Escherichia coli and Klebsiella pneumoniae in China. J Antimicrob Chemother 61:1003-1006. https://doi.org/10.1093/jac/dkn063

Kananizadeh P (2020) Emergence of carbapenem-resistant and colistinsusceptible Enterobacter cloacae complex co-harboring blaIMP-1 and $m c r-9$ in Japan. BMC Infect Dis 20:282. https://doi.org/10. 1186/s12879-020-05021-7

Kieffer N, Royer G, Decousser J-W, Bourrel A-S, Palmieri M, Ortiz De La Rosa J-M, Jacquier H, Denamur E, Nordmann P, Poirel $\mathrm{L}$ (2019) $m c r-9$, an inducible gene encoding an acquired phosphoethanolamine transferase in Escherichia coli, and its origin. Antimicrob Agents Chemother 63:e00965-e1019. https://doi.org/ 10.1128/AAC.00965-19

Li Y, Dai X, Zeng J, Gao Y, Zhang Z, Zhang L (2020) Characterization of the global distribution and diversified plasmid reservoirs of the colistin resistance gene mcr-9. Sci Rep 10:8113. https://doi.org/ 10.1038/s41598-020-65106-w

Lim LM, Ly N, Anderson D, Yang JC, Macander L, Jarkowski A, Forrest A, Bulitta JB, Tsuji BT (2010) Resurgence of colistin: a review of resistance, toxicity, pharmacodynamics, and dosing. Pharmacotherapy 30:1279-1291. https://doi.org/10.1592/phco. 30.12.1279

Mahaluca FA, Essack S, Sacarlal J (2018) Antibacterial Resistance Patterns of WHO List of Essential Antibiotics Adopted by Mozambique. J Antimicrob Agents. https://doi.org/10.4172/2472-1212. 1000183

Meunier D, Findlay J, Doumith M, Godoy D, Perry C, Pike R, Gronthoud F, Shryane T, Poirel L, Welfare W, Woodford N, Hopkins KL (2017) FRI-2 carbapenemase-producing Enterobacter cloacae complex in the UK. J Antimicrob Chemother 72:24782482. https://doi.org/10.1093/jac/dkx173

Nang SC, Li J, Velkov T (2019) The rise and spread of mor plasmidmediated polymyxin resistance. Crit Rev Microb 45:131-161. https://doi.org/10.1080/1040841X.2018.1492902

Nishida S, Matsunaga N, Kamimura Y, Ishigaki S, Furukawa T, Ono Y (2020) Emergence of Enterobacter cloacae complex Co-Producing IMP-10 and CTX-M, and Klebsiella pneumoniae Producing VIM-1 in Clinical Isolates in Japan. Microorganisms 8:1816. https://doi.org/10.3390/microorganisms8111816

Nordmann P, Naas T, Poirel L (2011) Global spread of Carbapenemase- producing Enterobacteriaceae. Emerg Infect Dis 17:8

Olaitan AO, Morand S, Rolain J-M (2014) Mechanisms of polymyxin resistance: acquired and intrinsic resistance in bacteria. Front Microbiol 5:643. https://doi.org/10.3389/fmicb.2014.00643

Olowo-okere A, Yacouba A (2020) Molecular mechanisms of colistin resistance in Africa: a systematic review of literature. Germs 10:367-379. https://doi.org/10.18683/germs.2020.1229

Osei Sekyere J (2016) Current state of resistance to antibiotics of lastresort in South Africa: a review from a public health perspective. Front Public Health 4:209. https://doi.org/10.3389/fpubh.2016. 00209

Osei Sekyere J (2019) mcr colistin resistance gene: a systematic review of current diagnostics and detection methods. MicrobiologyOpen 8:e00682. https://doi.org/10.1002/mbo3.682

Perez-Perez FJ, Hanson ND (2002) Detection of plasmid-mediated AmpC-lactamase genes in clinical isolates by using multiplex PCR. J Clin Microbiol 40:2153-2162. https://doi.org/10.1128/ JCM.40.6.2153-2162.2002

Pitout JDD, Nordmann P, Laupland KB, Poirel L (2005) Emergence of Enterobacteriaceae producing extended-spectrum $\beta$-lactamases (ESBLs) in the community. J Antimicrob Chemother 56:52-59. https://doi.org/10.1093/jac/dki166

Pons MJ, Vubil D, Guiral E, Jaintilal D, Fraile O, Soto SM, Sigaúque B, Nhampossa T, Aide P, Alonso PL, Vila J, Mandomando I, Ruiz J (2015) Characterization of extended-spectrum $\beta$-lactamases among Klebsiella pneumoniae isolates causing bacteraemia and urinary tract infection in Mozambique. J Glob Antimicrob Resist 3:19-25 
Ramirez D, Giron M (2020) Enterobacter Infections Jun 30. In: StatPearls [Internet]. Treasure Island (FL): StatPearls Publishing; 2021 Jan-. PMID: 32644722

Ribeiro TG, Novais Â, Peixe L, Machado E (2016) Atypical epidemiology of CTX-M-15 among Enterobacteriaceae from a high diversity of non-clinical niches in Angola: Table 1. J Antimicrob Chemother 71:1169-1173. https://doi.org/10.1093/jac/dkv489

Rossolini GM, D'Andrea MM, Mugnaioli C (2008) The spread of CTXM-type extended-spectrum $\beta$-lactamases. Clin Microbiol Infect 14:33-41. https://doi.org/10.1111/j.1469-0691.2007.01867.x

Rozwandowicz M, Brouwer MSM, Fischer J, Wagenaar JA, GonzalezZorn B, Guerra B, Mevius DJ, Hordijk J (2018) Plasmids carrying antimicrobial resistance genes in Enterobacteriaceae. J Antimicrob Chemother 73:1121-1137. https://doi.org/10.1093/ $\mathrm{jac} / \mathrm{dkx} 488$

Santajit S, Indrawattana N (2016) Mechanisms of antimicrobial resistance in ESKAPE pathogens. BioMed Res Int 2016:1-8. https:// doi.org/10.1155/2016/2475067

Sewunet T, Asrat D, Woldeamanuel Y, Ny S, Westerlund F, Aseffa A, Giske CG (2021) High prevalence of bla CTX-M-15 and nosocomial transmission of hypervirulent epidemic clones of Klebsiella pneumoniae at a tertiary hospital in Ethiopia. JAC-Antimicrob Resist 3:dlab001. https://doi.org/10.1093/jacamr/dlab001

Shawa M, Furuta Y, Mulenga G, Mubanga M, Mulenga E, Zorigt T, Kaile C, Simbotwe M, Paudel A, Hang'ombe B, Higashi H (2021) Novel chromosomal insertions of ISEcp1-blaCTX-M-15 and diverse antimicrobial resistance genes in Zambian clinical isolates of Enterobacter cloacae and Escherichia coli. Antimicrob Resist Infect Control 10:79. https://doi.org/10.1186/s13756-021-00941-8
Soliman AM, Maruyama F, Zarad HO, Ota A, Nariya H, Shimamoto T, Shimamoto T (2020) Emergence of a multidrug-resistant Enterobacter hormaechei clinical isolate from Egypt co-harboring mcr-9 and blaVIM-4. Microorganisms 8:595

Sumbana JJ, Santona A, Fiamma M, Taviani E, Deligios M et al (2021) Extraintestinal Pathogenic Escherichia coli ST405 Isolate Coharboring blaNDM-5 and blaCTXM-15: A New Threat in Mozambique. Microb Drug Resist 27:1633-1640.https://doi.org/10.1089/ mdr.2020.0334

Uhlemann A-C (2019) Multidrug-resistant Enterobacter cloacae complex emerging as a global, diversifying threat. Front Microbiol 10:8

Wang C, Feng Y, Liu L, Wei L, Kang M, Zong Z (2020) Identification of novel mobile colistin resistance gene $\mathrm{mcr}$-10. Emerg Microb Infect 9:508-516. https://doi.org/10.1080/22221751.2020.17322 31

Zeynudin A, Pritsch M, Schubert S, Messerer M, Liegl G, Hoelscher M, Belachew T, Wieser A (2018) Prevalence and antibiotic susceptibility pattern of CTX-M type extended-spectrum $\beta$-lactamases among clinical isolates of gram-negative bacilli in Jimma, Ethiopia. BMC Infect Dis 18:524. https://doi.org/10.1186/ s12879-018-3436-7

Publisher's Note Springer Nature remains neutral with regard to jurisdictional claims in published maps and institutional affiliations. 